\title{
Evaluation of the physical-mechanical properties of cement-lime based masonry mortars produced with mixed recycled aggregates
}

\author{
R.L.S. Ferreira ${ }^{a}$, M.A.S. Anjos ${ }^{b}$, E.F. Ledesma ${ }^{c} \bowtie$, J.E.S. Pereira ${ }^{\mathrm{d}}$, A.K.C. Nóbrega ${ }^{\mathrm{e}}$ \\ a. Federal University of Rio Grande do Norte, Civil Engineering Department, Natal (Brazil) \\ b. Federal Institute of Education, Science and Technology of Paraiba, Civil Construction Department, João Pessoa (Brazil) \\ c. Área de Mecánica de Medios Continuos y Teoría de Estructuras, Universidad de Córdoba, (Spain) \\ d. University of Rio Grande do Norte, Chemical Engineering Department, Natal (Brazil) \\ e. Federal University of the Semi-arid, Engineering of Department, Angicos (Brazil) \\ $\triangle$ efledesma@uco.es
}

\begin{abstract}
This study investigated the physical-mechanical effects of cement-lime mortars containing recycled aggregate of construction and demolition waste (CDW). The natural aggregate (NA) was replaced by volume at $25 \%, 50 \%, 75 \%$ and $100 \%$ by mixed recycled aggregate (MRA) obtained from the CDW crushing. Five types of mortars were prepared with a volumetric ratio of 1:1:6 (cement, lime and aggregate) and water/binder ratio based on the fixed consistency of $260 \mathrm{~mm}$. The effects of MRA on fresh and hardened mortars' properties were analyzed. The results were analyzed using a one-way ANOVA. MRA incorporation improved most of the physical-mechanical properties of mortars tested, except for hardened bulk density, water absorption and porosity. In the long-run, mechanical strengths significantly increased in all compositions, especially those with higher percentages of MRA. The results obtained showed that the use of MRA in masonry mortars is an alternative to reduce the generation of waste and consumption of natural resources.
\end{abstract}

KEYWORDS: Mortar; Mechanical properties; Physical properties; Compressive strength; Waste treatment.

Citation/Citar como: Ferreira, R.L.S.; Anjos, M.A.S.; Ledesma, E.F.; Pereira, J.E.S.; Nóbrega, A.K.C. (2020) Evaluation of the physical-mechanical properties of cement-lime based masonry mortars produced with mixed recycled aggregates. Mater. Construcc. 70 [337], e210 https://doi.org/10.3989/mc.2020.02819

RESUMEN: Evaluación de las propiedades físico-mecánicas de morteros de albañilería producidos en base de cemento y cal con áridos reciclados mixtos. Este estudio investigó los efectos físico-mecánicos de los morteros de cemento y cal con áridos reciclados de residuos de construcción y demolición (RCD). El árido natural (AN) se reemplazó en volumen al 25\%,50\%,75\% y 100\% por el árido reciclado mixto (ARM) obtenido de la trituración de RCD. Se prepararon cinco tipos de morteros con una relación volumétrica de 1: 1: 6 (cemento, cal y áridos) y una relación de agua / aglomerante en función de la consistencia fija de $260 \mathrm{~mm}$. Se analizaron los efectos del ARM en las propiedades de los morteros frescos y endurecidos. Los resultados se analizaron utilizando un ANOVA-simple. La incorporación de ARM mejoró la mayoría de las propiedades físico-mecánicas de los morteros, excepto la densidad aparente endurecida, la absorción de agua y la porosidad. A largo plazo, las resistencias mecánicas aumentaron significativamente en todas las composiciones, especialmente en aquellas con porcentajes más altos de ARM. Los resultados obtenidos mostraron que el uso de ARM en morteros de albañilería es una alternativa para reducir la generación de residuos y el consumo de recursos naturales.

PALABRAS CLAVE: Mortero; Propiedades mecánicas; Propiedades físicas; Resistencia a compresión; Tratamiento de residuos.

ORCID ID: R.L.S. Ferreira (https://orcid.org/0000-0001-6744-5395); M.A.S. Anjos (https://orcid.org/0000-0001-95632534); E.F.Ledesma (https://orcid.org/0000-0002-3744-3791); J.E.S. Pereira (https://orcid.org/0000-0002-7612-0303); A.K.C. Nóbrega (https://orcid.org/0000-0002-9481-5408)

Copyright: (C) 2020 CSIC. This is an open-access article distributed under the terms of the Creative Commons Attribution 4.0 International (CC BY 4.0) License. 


\section{INTRODUCTION}

The construction industry has increased the consumption of natural resources, including water and energy, as well as the emission of gaseous pollutants and waste generation. It has become clear that construction can be considered one of the industries that most contributes to changing the environment (1-3).

The large and complex production chain of the construction industry is responsible for consuming more raw materials (around $3000 \mathrm{Mt} / \mathrm{year}$ ) than any other economic activity, which emphasizes its unsustainable character (4). It is also estimated that the construction sector is responsible for the consumption of about $40 \%$ of all natural resources available on the planet (5) and that $1 / 3$ of these resources are converted to cement-based products (6). As an example, global aggregate production almost doubled from 21 billion tons in 2007 to 40 billion tons in 2014 (7).

Thereby, the recycling and reuse of construction and demolition waste (RCD) in engineering works are highlighted, mainly due to the high levels of generation of this waste and the consequent irregular destination. In Brazil, although there are laws on recycling, the production of $\mathrm{CDW}$ is estimated at over $70 \mathrm{Mt}(8,9)$. Currently, only $6.14 \%$ of this volume is recycled (7) and the upper part is destined for landfills inert or illegally by other means, as such as abandoned land and roadsides. As a consequence, the environment is affected by the siltation of rivers and lakes, obstruction of urban drainage systems (causing flooding), degradation of urban landscapes, the proliferation of vectors that are harmful to human health, etc. $(10,11)$.

The use of recycled aggregates (RA) derived from the crushing CDW as substitutes for natural aggregates (NA) to produce new building products arises with the most efficient alternative to add value to these materials. Although undesirable materials (asphalt, plastic, wood, rubber, glass, gypsum, etc.) can be found, the RA of CDW for the production of cement materials can be divided into Recycled Concrete Aggregates (RCA), Recycled Masonry Aggregate (RMA) e Mixed Recycled Aggregates (MRA) (12). The Brazilian standard (NBR 15116, 2004) establishes that RA should be composed of less than $90 \%$, by mass, of Portland cement-based fragments and NA.

Researchers have proven that the incorporation of RA in mortars may enhance the performance (2, 13-23), mainly because they are materials that do not perform structural function and their mechanical requirements are less rigorous - their behaviour depends much more of adhesion between the substrate and mortar than of the intrinsic mechanical properties of the mortar (24). It is also worth noting the interest in using RA in mortars, the fact that the fine fraction (particles smaller than $4.8 \mathrm{~mm}$ ) is unintentionally produced and usually not used (13), which represents a large amount of the weight of the processed CDW which, in general, corresponds to about 40 to $50 \%(8,25,26)$.

However, the use of the recycled aggregate obtained from recycling plants (i.e., the MRA) for the production of building materials has been studied to a lesser extent. Previous research investigated the use of a single type of CDW of RA (RCA and RMA, for example), limiting comparisons on the effect of the recycled aggregate with different compositions. The reasons seem to be evident since the aggregates have a high water absorption and susceptible to the presence of contaminants (25), thus affecting directly the properties of concrete (27-31) and mortars (16,32-34). As a result, the recycling of mixed CDW occurs slowly, contributing even more to the problems involved in the generation and destination of these wastes due to a large amount of MRA that is stored in recycling plants without alternatives that potentiate their recovery.

Andrade et al. (13) compared the use of ceramic recycled aggregate (CRA) and MRA in the mechanical properties of mortars produced with different RA contents replacing the NA $(25 \%, 50 \%, 75 \%$ and $100 \%$ ). The results showed that the mortars with MRA presented worse performance when compared to mortars produced with CRA. However, MRA mortars have a greater potential for capturing $\mathrm{CO}_{2}$ from the atmosphere, especially at high replacement rates $(>50 \%)$, which is beneficial from the environmental point of view.

Muñoz-Ruiperez et al. (2) studied the influence of the addition of MRA and RCA on lightweight masonry mortars produced with two types of expanded clay. In general, its ware observed that the performance of the mortars containing RA is slightly bottom to the mortars with NA, especially when the MRA ware used due to the higher water/binder ratio $(w / b)$ of these compositions.

Restuccia et al. (20) investigated the incorporation of MRA (in dry and washed condition) in mortars and concluded that regardless of the condition of the RA, its incorporation caused a decrease in the mechanical strength of the mortars. However, mortars with 50\% MRA in washed condition, together with the superplasticizer additive, presented better results. Similar to the research proposal of these last authors, Cuenca-Moyano et al. (15) evaluated the effects of pre-soaked of the MRA on the properties of masonry mortars. The results indicated that although the mortars with MRA presented inferior performance to that of mortars with NA, the presoaked method was beneficial for the improvement of the properties in the fresh state (bulk density and air content incorporated) and hardened (mechanical strength). 
Note also that the number of researches that investigates the use of the RA in cement-lime based mortars are limited, although previous studies have shown the beneficial effect of using lime as a primary or secondary binder in compaction of mortars and, consequently, in their physical and mechanical properties $(19,22,35)$.

Corinaldesi (35) investigated the use of mortars with the incorporation of RA for the repair of historical buildings. For this purpose, cement and hydraulic lime mortars by weight ratio of $1: 3$ (binder and aggregate) and 100\% replacement of the NA by the RA obtained from ceramic bricks were produced. The authors observed that the types of binders and aggregates appear to influence the microstructure of mortars, especially when using hydraulic lime and RA of fine size.

Martínez et al. (19) compared the properties of mortars based on cement and hydrated lime produced with three types of RA (concrete, ceramics and masonry residues). The authors have shown that the use of RA and any filler material (hydrated lime, limestone filler or slag) improves the properties of mortars compared to mortars produced with NA.

Samiei et al. (22) studied the influence of the incorporation of RA produced from high-quality concrete residues in cement and hydraulic mortars (cement and hydraulic lime), with the mass ratio of $1: 3$ and 1:1:6, respectively. As expected, cement mortars presented superior mechanical performance than cement-lime mortars. However, cement mortars presented a decrease in mechanical strength when the NA was replaced by the RA. On the other hand, for mixed mortars, the incorporation of RA resulted in improvement of mechanical properties by up to $60 \%$.

For these reasons, the use of fillers as such as lime in the composition of cement mortars becomes important, both viewpoint technically and environmentally. It is possible to improve the properties of mortars (workability, water retention, absorbing deformations, etc.) and reduce the consumption of cement, minimizing the environmental impacts resulting from the production of clinker.

This study investigated the effect of replacement of NA by RA obtained from mixed CDW crushing on the physical and mechanical properties of cement-lime mortars. Thus, this study aimed to contribute to a database on the subject, in order to encourage the use of the MRA in construction materials and, consequently, to promote the sustainable development of the construction industry. In this sense, the incorporation of aggregates produced in CDW recycling plants into masonry mortars suggests a path for the construction industry, which is compatible with the sustainable connotation.

\section{MATERIALS AND METHODS}

\subsection{Materials}

In this study, the Brazilian Pozzolanic Portland cement (CEM) (similar to ASTM C 595 Portland Pozzolanic) was used, with a density of $3.15 \mathrm{~g} / \mathrm{cm}^{3}$, a bulk density of $1.04 \mathrm{~kg} / \mathrm{dm}^{3}$, a specific surface BET of $3.28 \mathrm{~m}^{2} / \mathrm{g}, 27.7 \mu \mathrm{m}$ and compressive strength of $30 \mathrm{MPa}$ at 28 days. As a complimentary binder was used hydrated lime (HL) of type $\mathrm{CH}-\mathrm{I}$ (similar to ASTM C207-6) with a density of $2.30 \mathrm{~g} / \mathrm{cm}^{3}$, bulk density of $0.42 \mathrm{~kg} / \mathrm{dm}^{3}$, specific surface BET of 6.74 $\mathrm{m}^{2} / \mathrm{g}$ and the average diameter of the particles of $2.77 \mu \mathrm{m}$. The use of hydrated lime is justified by its beneficial effect on the properties of mortars and the reduction of cement consumption, as mentioned previously.

Two different aggregates were used in this study: river siliceous sand as the NA and recycled sand produced in a CDW recycling plant located in São José do Mipibú (RN, Brazil) as the MRA. The MRA was collected from piles stored in the recycling plant (Figure 1) and after sieved in the laboratory to remove particles larger than $4 \mathrm{~mm}$. The mortar and concrete $(74.43 \%)$, aggregates with a small or no amount of mortar adhered (17.64\%) and ceramic materials $(9.32 \%)$ were the main constituents of the MRA, determined from the manual separation of grains retained in the $2.36 \mathrm{~mm}$ sieve. Other minor components were also present, such as gypsum particles $(0.55 \%)$ and other materials $(0.05 \%$, styrofoam, wood, paper, etc.).

Table 1 shows the physical characteristics of the studied aggregates. In comparison to the NA, the MRA showed a greater fine content $(<75 \mu \mathrm{m})$, greater fineness modulus, greater friability coefficient, greater water absorption, less apparent specific gravity and less bulk density. These results are similar to those obtained in other studies on the characteristics of fine recycled sands from CDW $(13,18,36)$ and, in general, meet the limits established by Standard Brazilian (NBR 15116, 2004) and European (UNE-EN 13139:2002).

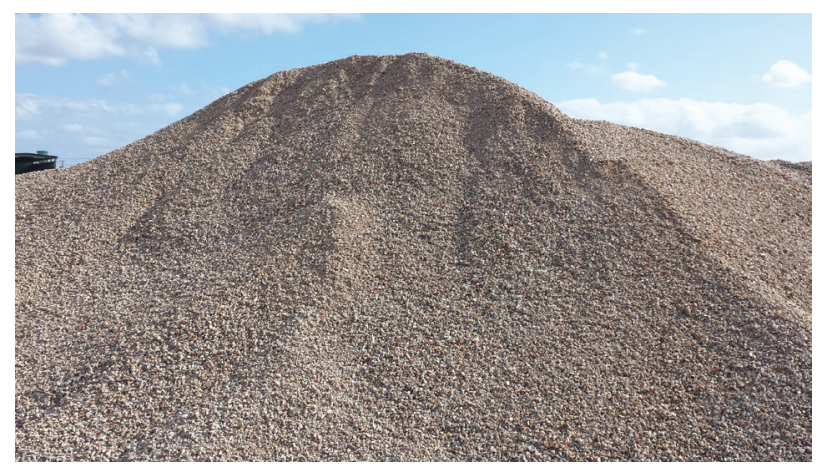

FIGURE 1. Pile of recycled aggregates in a recycling plant. 
TABLE 1. Physical characterization of the analyzed aggregates.

\begin{tabular}{|c|c|c|c|c|c|}
\hline Characteristic & Brazilian standard & NA & MRA & $\begin{array}{c}\text { Limit set by NBR } \\
\text { 15116, (2004)* }\end{array}$ & $\begin{array}{c}\text { Limit set by } \\
\text { UNE-EN 13139** }\end{array}$ \\
\hline Fine content $(\%)$ & NBR NM 46 (2003) & 2.0 & 8.3 & $\leq 20$ & $\leq 8$ \\
\hline Oven-dry particles density $\left(\mathrm{kg} / \mathrm{dm}^{3}\right)$ & NBR NM 52 (2009) & 2.64 & 2.52 & No limit & No limit \\
\hline Bulk density $\left(\mathrm{kg} / \mathrm{dm}^{3}\right)$ & NBR NM 45 (2006) & 1.50 & 1.30 & No limit & No limit \\
\hline Fineness modulus & NBR NM 248 (2003) & 1.37 & 2.54 & No limit & No limit \\
\hline Maximum size (mm) & NBR NM 248 (2003) & 0.60 & 4.75 & No limit & No limit \\
\hline Water absorption (\%) & NBR NM 30 (2001) & 1.34 & 6.09 & $\leq 17$ & No limit \\
\hline Friability coefficient (\%) & NBR 7218 (2010) & 0.23 & 1.82 & 2.0 & No limit \\
\hline Bulking coefficient & NBR 6467 (2009) & 1.33 & 1.19 & - & - \\
\hline Uniformity coefficient $(\mathrm{Cu})$ & - & 2.60 & 3.60 & - & - \\
\hline
\end{tabular}

* Requirements for MRA used in non-structural concrete.

** Requirements for RA used in mortars.

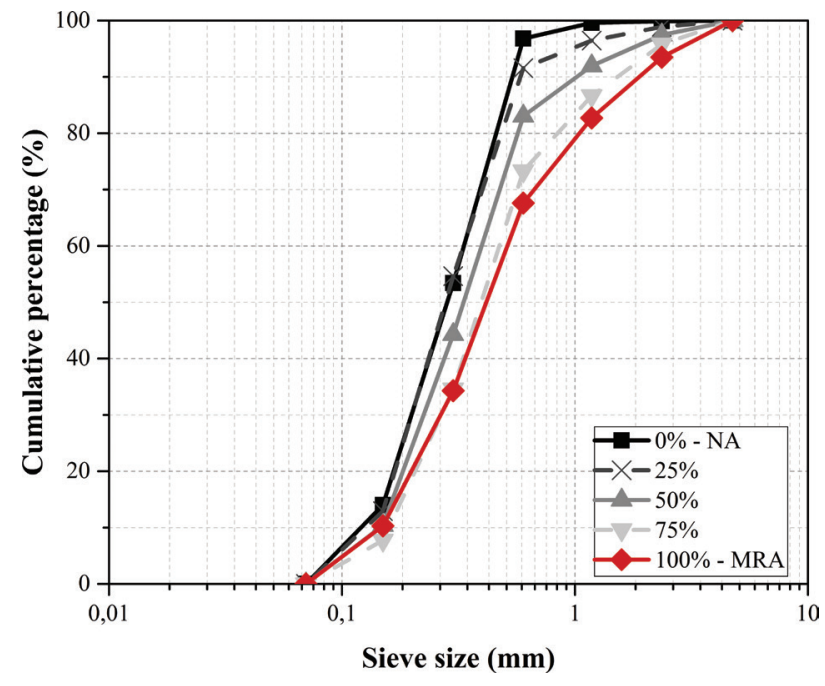

FIGURE 2. Particle size distribution of the natural and recycled aggregates.

Figure 2 shows the particle size distribution of the studied aggregates, determined according to the Brazilian standard NBR NM 248 (2003) (Corresponding to UNE-EN 933-1:2006) and the influence of NA replacement by MRA in the sand curves.

The incorporation of the MRA improved the grain size distribution of the mixtures due to the better distribution of the MRA particle size, which justifies the higher uniformity coefficient (Table 1) of this aggregate when compared to NA. Similar results were obtained in other researches $(19,21)$, in which it was observed that the studied RA presented a more adequate particle size distribution than NA.

Figure 3 shows the mineralogical composition determined by X-Ray diffraction (XRD) using a Shimadzu XRD-6000 instrument with $\mathrm{CuK} \alpha$ radiation. The main crystalline phase in both cases was quartz $\left(\mathrm{SiO}_{2}\right)$.

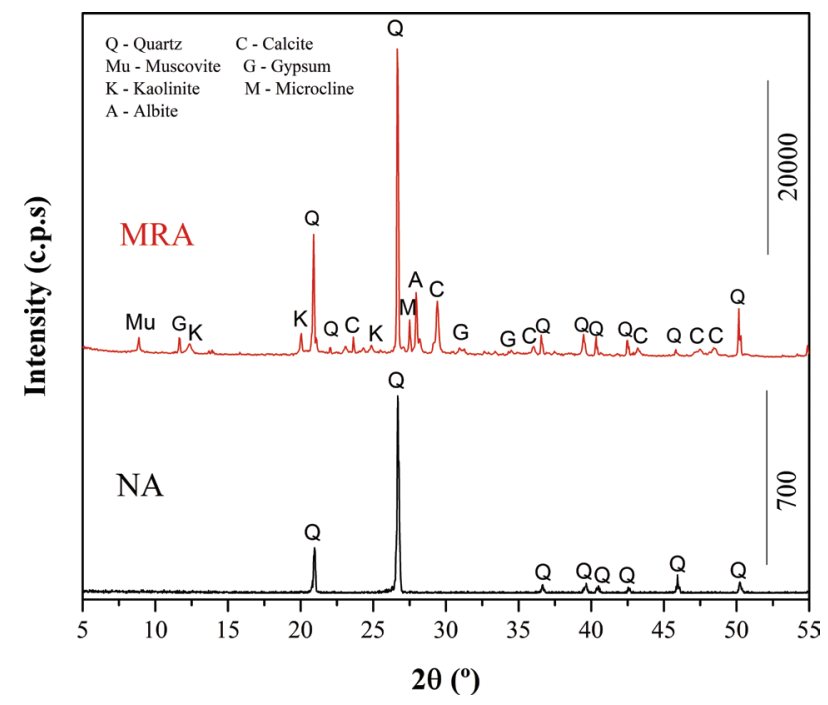

FIGURE 3. XRD of the aggregates.

Calcite $\left(\mathrm{CaCO}_{3}\right)$ was present only in the MRA. Other phases as such as muscovite $\left[\mathrm{KAl}_{2}\left(\mathrm{AlSi}_{3} \mathrm{O}_{10}\right)\right.$ $\left.(\mathrm{F}, \mathrm{OH})_{2}\right]$, gypsum $\left[\mathrm{CaSO}_{4}\left(\mathrm{H}_{2} \mathrm{O}\right)_{2}\right]$, kaolinite $\left[\mathrm{Al}_{2} \mathrm{Si}_{2} \mathrm{O}_{5}(\mathrm{OH})_{4}\right]$, microcline $\left(\mathrm{KAlSi}_{3} \mathrm{O}_{8}\right)$ and albite $\left(\mathrm{NaAlSi}_{3} \mathrm{O}_{8}\right)$ were identified at lower intensities in the MRA. The identification of gypsum in MRA coincides with the composition of the RCD, previously mentioned. RA contaminated with gypsum in cementitious materials may degradee the cementitious matrix, due to the formation of secondary ettringite (34). The presence of quartz and calcite in the MRA was also observed by other authors $(8,20,32,36)$ and reinforce the results obtained by Saiz Martínez et al. (21), where these authors identified that for the three types of RA analyzed (concrete, ceramic and mixed) the presence of quartz and calcite was preponderant.

The chemical analyzes of the aggregates were performed by X-ray fluorescence (XRF) in the 
EDX-720 equipment Shimadzu, using the semiquantitative method and under vacuum atmosphere. The Table 2 shows the chemical analysis of the aggregates.

The chemical composition of NA was predominantly silicon oxide (>95\%). For the MRA, the highest levels of silicon oxide $\left(\mathrm{SiO}_{2}, 40.40 \%\right)$, calcium oxide $(\mathrm{CaO}, 29.83 \%)$ and aluminum oxide $\left(\mathrm{Al}_{2} \mathrm{O}_{3}, 10.18 \%\right)$. Small quantities of sulfuric oxide $\left(\mathrm{SO}_{3}, 5.03 \%\right)$ were detected in MRA, which coincided with the mineralogy's characteristics and composition of CDW. Angulo et al. (25) commented that the origin of different oxides in RA of CDW is associated with several types of silicates that are derived from the particles of hardened cement paste and natural aggregates, natural rocks, red ceramics, etc. This diversity of MRA constituents may influence the mechanical and durability properties of mortars (21).

\subsection{Production of mortars}

The following criteria were established for the manufacture of mortar:

- The unit trace in 1:1:6 volume (cement: lime: wet aggregate) was defined, commonly used in civil construction in Brazil. The NA was replaced in volume by MRA at $0 \%, 25 \%, 50 \%, 75 \%$ and $100 \%$. Finally, the same trace was converted to mass with the aggregate in dry condition, using its respective bulk densities, bulking coefficients and percentages of substitution the NA by MRA, according to Eq. [1]:

$$
\begin{aligned}
1:(L H) & \times \frac{\delta_{L H}}{\delta_{C E M}}:\left(\frac{\% N A \times V_{h}}{100 \times B C_{N A}}\right) \\
& \times \frac{\delta_{N A}}{\delta_{C E M}}:\left(\frac{\% M R A \times V_{h}}{100 \times B C_{M R A}}\right) \times \frac{\delta_{M R A}}{\delta_{C E M}}
\end{aligned}
$$

Where: $L H$ is the volume proportion of hydrated lime; $\% N A$ e $\% M R A$ correspond to the replacement percentage of NA and MRA, respectively, in relation to the aggregate volume in moist condition $\left(V_{h}=6\right) ; \delta_{C E M}, \delta_{L H}, \delta_{N A}$ e $d_{M R A}$, correspond respectively to the bulk density of cement, lime hydrated, NA and MRA in $\mathrm{kg} / \mathrm{dm}^{3} ; B C_{N A}$ e $B C_{M R A}$ correspond to the bulking coefficients of NA and MRA, respectively.

- Therefore, five mortars were tested: MRA-100/0 (reference), MRA-75/25, MRA-50/50, MRA25/75 e MRA-0/100;

- The consistencies of fresh mortars was kept constant at $260 \mathrm{~mm}$ in all mixes according to the Brazilian standard NBR 13276 (2016) (similar to ASTM C1329/C1329M, 2016). Thus, the ideal water content for mixing the mortars was set experimentally to ensure the flow value specified.

- The following formula [Eqs. 2 to 5] were used to calculate the dry mass of each component per $\mathrm{m}^{3}$ of mortar produced (Table 3 ):

$$
C_{C E M}=\frac{\rho_{\text {mortar }}}{1+L H_{w t}+N A_{w t}+M R A_{w t}+w / c}
$$

TABLE 2. X-ray fluorescence of the aggregates.

\begin{tabular}{lcccccccccc}
\hline & \multicolumn{10}{c}{ \% oxides (by mass) } \\
\cline { 2 - 12 } Aggregates & $\mathbf{S i O}_{2}$ & $\mathbf{C a O}$ & $\mathbf{A l}_{2} \mathbf{O}_{3}$ & $\mathbf{F e}_{2} \mathbf{O}_{3}$ & $\mathbf{S O}_{3}$ & $\mathbf{K}_{2} \mathbf{O}$ & $\mathbf{S r O}$ & $\mathbf{Z r O}_{2}$ & $\mathbf{T i O}_{2}$ & $\mathbf{O t h e r s}$ \\
\hline NA & 95.81 & - & 2.38 & - & 0.13 & - & - & - & 0.94 & 0.74 \\
MRA & 40.40 & 29.83 & 10.18 & 8.91 & 5.03 & 1.57 & 1.13 & 0.99 & 0.76 & 1.20 \\
\hline
\end{tabular}

TABLE 3. Mortar mixture proportions.

\begin{tabular}{lcccccccc}
\hline & \multicolumn{9}{c}{ Proportions $\left(\mathbf{k g} / \mathbf{m}^{3}\right)$} \\
\cline { 3 - 9 } Mortar type & NA/MRA (\%) & CEM & HL & NA & MRA & Water & w/c & w/c effective \\
\hline MRA-100/0 & $100 / 0$ & 218.14 & 88.09 & 1419.35 & 0 & 296.35 & 1.36 & 1.27 \\
MRA-75/25 & $75 / 25$ & 215.29 & 86.94 & 1050.61 & 360.09 & 300.12 & 1.39 & 1.23 \\
MRA-50/50 & $50 / 50$ & 211.46 & 85.40 & 687.95 & 707.38 & 317.74 & 1.50 & 1.26 \\
MRA-25/75 & $75 / 25$ & 210.29 & 84.92 & 342.07 & 1055.18 & 324.24 & 1.54 & 1.21 \\
MRA-0/100 & $100 / 0$ & 207.84 & 83.93 & 0 & 1390.51 & 339.13 & 1.63 & 1.21 \\
\hline
\end{tabular}

NA/RCA - percentage in volume of natural aggregates/percentage of mixed recycled aggregate.

CEM - Cement; HL - Hydrated Lime.

MRA - Mixed Recycled Aggregate.

NA - Natural Aggregate; w/c - water/cement ratio. 
$C_{L H}=C_{C E M} \times L H_{w t}$

$C_{N A}=C_{C E M} \times N A_{w t}$

$C_{M R A}=C_{C E M} \times M R A_{w t}$

Where: $C_{C E M}, C_{L H}, C_{A N}$ and $C_{M R A}$ is the consumption of cement, hydrated lime, NA and MRA in $\mathrm{Kg} / \mathrm{m}^{3}$ of produced mortar, respectively; pmortar is the bulk density of the fresh mortar determined in accordance with the Brazilian standard NBR 13278 (NBR 13278, 2005) in $\mathrm{kg} / \mathrm{m}^{3}$ (see Table 5); $L H_{w t}, N A_{w t}$ e MRA $A_{w t}$ correspond to the proportion in $\mathrm{kg}$ / kg of hydrated lime, NA and MRA, respectively, determinate in Eq. (1); w/c is the water/cement ratio in $\mathrm{kg} / \mathrm{kg}$.

- The mortars were mixed in a standard mechanical mixer according to the procedure described by Brazilian Standard (NBR 16541, 2016).

The incorporation of the MRA resulted in a linear increase in the content of requested water to obtain the same consistency due to higher water absorption of these aggregates compared to natural sand. The irregular shape and texture of the MRA also explain the increase in the $w / b$ ratio when using MRA instead of NA. Similar behaviors were observed in other studies $(2,13,15,18,20,32,34$, 37). The consumption of cement and lime decreases slightly with an increase in MRA content, considering the same volume $\left(1 \mathrm{~m}^{3}\right)$. The reason for this decrease is the difference between the specific mass of the natural and recycled aggregates.

\subsection{Tests on mortar mixes}

During the first 48 hours, the surface of the specimens was protected with a glass plate to avoid evaporation of the kneading water. After this period, demoulding was carried out, keeping the specimens exposed to air and at room temperature of $25 \pm 5$ ${ }^{\circ} \mathrm{C}$ until the ages established for each test. Details regarding the specimen size and numbers with the applicable standards and curing time for these tests are listed in Table 4.

\subsection{Statistical analysis}

The properties studied were analyzed using a univariate analysis of variance to determine if the percentage of NA substitution by MRA had a statistically significant effect. In addition, the Tukey

TABLE 4. Tests performed on mortars and their respective methods and standards.

\begin{tabular}{llcc}
\hline Properties & Brazilian Standard & Specimens & Curing time \\
\hline Properties of fresh mortar & & & - \\
Bulk density & NBR 13278 (2005) & 4 & \\
Entrained air content & NBR 13278 (2005) & 4 & 28 days \\
Properties of hardened mortar & & & $28,91,150$ days \\
Dry bulk density & NBR 13280 (2005) & \\
Flexural strength & NBR 13279 (2005) & 4 & $28,90,150$ days \\
Compressive strength & NBR 13279 (2005) & 4 & 28 days \\
Water absorption and porosity & NBR 9778 (2009) & 8 & 28 days \\
Capillary water absorption & NBR 15259 (2005) & 4 & 4 \\
\hline
\end{tabular}

${ }^{1}$ Equivalent to EN 1015-6 (1998).

${ }^{2}$ Equivalent to EN 1015-7 (1998).

${ }^{3}$ Equivalent to EN 1015-10 (1999).

${ }^{4,5}$ Equivalent to EN 1015-11 (1999) or ASTM C1314 (2016).

${ }^{6}$ Equivalent to EN 1936 (2007); ${ }^{7}$ Equivalent to EN 1015-18 (2002).

TABLE 5. The bulk density of fresh mortar.

\begin{tabular}{lccc}
\hline Mortar & Bulk density $\left(\mathbf{k g} / \mathbf{m}^{\mathbf{3}}\right)$ & SD $\left(\mathbf{k g} / \mathbf{m}^{\mathbf{3}}\right)$ & Homogeneous groups* \\
\hline MRA-100/0 & 2021.93 & 2.83 & $\mathrm{a}$ \\
MRA-75/25 & 2013.05 & 3.50 & $\mathrm{~b}$ \\
MRA-50/50 & 2009.92 & 3.20 & $\mathrm{~b}$ \\
MRA-25/75 & 2016.71 & 2.27 & $\mathrm{ab}$ \\
MRA-0/100 & 2021.41 & 2.02 & $\mathrm{a}$ \\
\hline
\end{tabular}


test was also performed with Statistica 7.0 software (StatSoft Co., USA) for multiple comparisons $(\mathrm{p}<0.05)$ to determine which substitution levels were significantly different from the others, based on the results obtained properties in the fresh and hardened state. Homogeneous groups were identified using columns of lower case letters, characterizing the quantity (order of the means) and the relation between them.

\section{RESULTS AND DISCUSSION}

\subsection{Properties of fresh mortar}

\subsubsection{Bulk density of fresh mortar}

The incorporation of the MRA resulted in mortars with lower fresh bulk density (Table 5). From a statistical standpoint, the p-value of the F-test was less than 0.05 (p-value $=0.0003$ ). Thus, the bulk density of the fresh mortar was affected by the incorporation of fine MRA. Based on the homogeneous groups, no statistically significant differences were found between the bulk density of fresh reference mortar (MRA-100/0) and those produced with $75 \%$ and $100 \%$ replacement (MRA-25/75 and MRA-0/100, respectively).

It can be seen in Figure 4 that no linear trend of reduction of fresh bulk density with the incorporation of MRA, as observed in previous studies $(15,18,38)$. However, mortars with MRA studied showed a slightly higher bulk density as MRA content increased. This could be due to the higher uniformity coefficient of the MRA and the filling effect of the voids by the fine particles of this RA, resulting in mortars that are more compact. Previous studies have shown that the largest number of particles for the same volume of mortar (15), as well

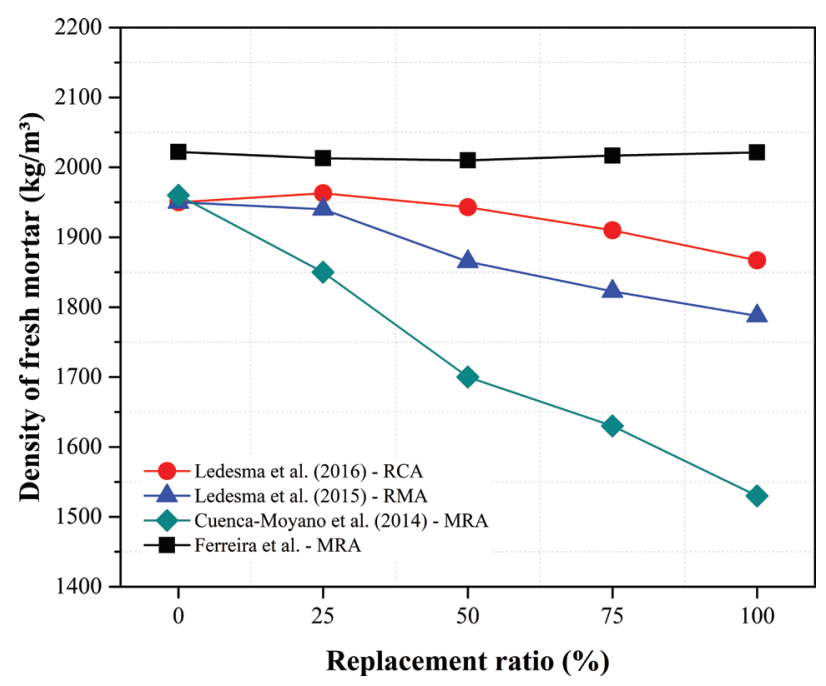

FIGURE 4. Bulk density of fresh mortar vs. replacement ratio. as filling voids filled with water by smaller particles $(<0.15 \mathrm{~mm})$ of the MRA (39) increased the density of the fresh mortar.

\subsubsection{Entrained air content}

The incorporation of the MRA resulted in mortars with less amount of entrained air content (Table 6). The higher amount of fines and the greater presence of friable grain of the MRA effectively contribute to decreasing voids in the mixture. According to Corinaldesi (35) when larger amounts of fine particles $(<0.063 \mathrm{~mm})$ are used, the number of macropores decreases due to the filler effect and, consequently, the volume of occluded air decreases. Fernández-Ledesma et al. (38) pointed out that the included air content this is not a limiting property in masonry mortar and, therefore, a maximum replacement ratio of $100 \%$ can be used to ensure proper performance in terms of entrained air content.

Statistically, the p-value of the F-test was less than $0.05(p$-value $=0.0000)$ and indicates that there were significant differences between the values found. However, the results obtained in the Tukey test indicated that reference mortars (MRA-100/0) and 25\% substitution (MRA-75/25) do not have statistically significant differences for the entrained air content, whereas the other replacement percentages differ.

Although the statistical results indicated differences, the entrained air content mean values, decreased linearly $\left(\mathrm{R}^{2}=0.98\right)$ as the fine MRA content increased (Figure 5), corroborating with other researches $(18,38)$ and contrary to the results obtained by Cuenca-Moyano et al. (15). The worst performance obtained by these authors in terms of embedded air can be attributed to the greater amount of RA used and therefore the higher w/b ratio used in the manufacture of their mortars when compared to this study.

\subsection{Properties of hardened mortar}

\subsubsection{Dry bulk density hardened mortar}

Figure 6 shows a linear $\left(R^{2}=0.94\right)$ decrease of the mean values of bulk density of hardened mortar, which was due to the lower density of MRA. This behaviour

TABLE 6. Occluded air content.

\begin{tabular}{lccc}
\hline Mortar & $\begin{array}{c}\text { Occluded air } \\
(\mathbf{\%})\end{array}$ & $\begin{array}{c}\text { SD } \\
(\%)\end{array}$ & $\begin{array}{c}\text { Homogeneous } \\
\text { groups* }\end{array}$ \\
\hline MRA-100/0 & 6.34 & 0.52 & $\mathrm{a}$ \\
MRA-75/25 & 5.77 & 0.65 & $\mathrm{a}$ \\
MRA-50/50 & 4,15 & 0.60 & $\mathrm{~b}$ \\
MRA-25/75 & 2.85 & 0.43 & $\mathrm{c}$ \\
MRA-0/100 & 1.13 & 0.23 & $\mathrm{~d}$ \\
\hline
\end{tabular}




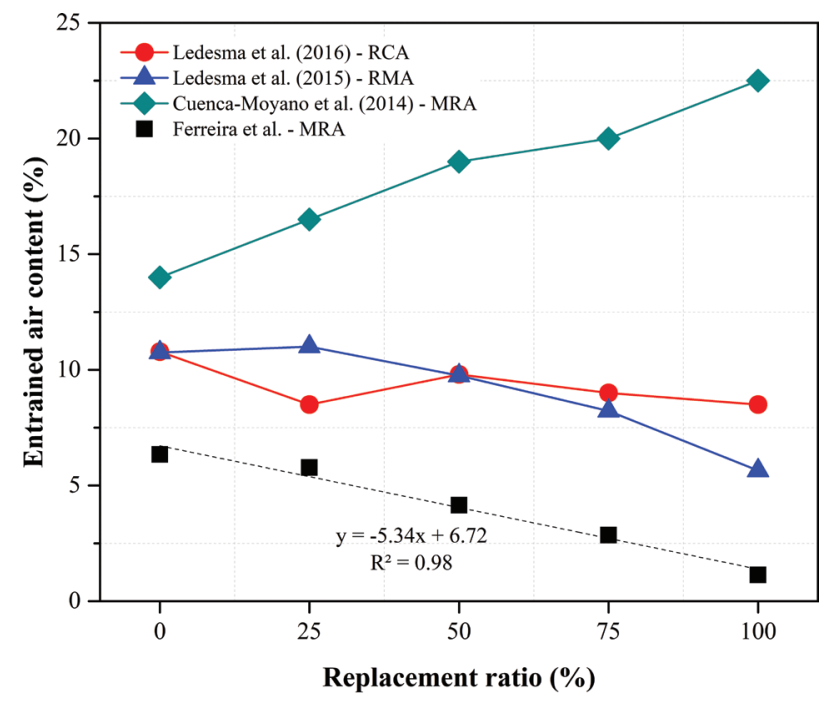

FIGURE 5. Entrained air content vs. replacement ratio.

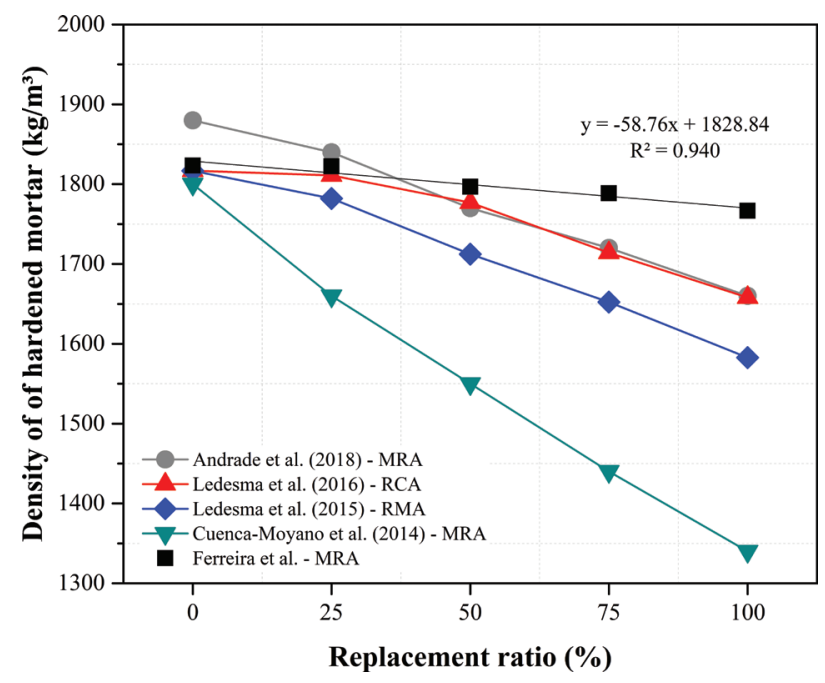

FIGURE 6. Dry bulk density vs. replacement ratio.

was also observed in previous studies $(13,15,18,38)$. The reason for the lower dry bulk density obtained by Andrade et al. (13), Ledesma et al. (18) and FernándezLedesma et al. (38) is the same as that for the decrease of the fresh bulk density, that is, the lower density of the RA used contributes to the observed decrease. In addition to the lower density of RA, the results obtained by Cuenca-Moyano et al. (15) can be attributed to the higher $\mathrm{w} / \mathrm{b}$ ratios used in the mixes.

The $\mathrm{p}$-value of the F-test was less than 0.05 ( $p$-value $=0.0001)$, which indicates that the percentage of NA replacement by MRA had a significant effect on this property. Table 7 shows that three homogeneous groups were identified in the multiple range tests. The results showed that there were no statistically significant differences between the mean values of mixes with replacement ratios below $50 \%$.
TABLE 7. Dry bulk density hardened mortar.

\begin{tabular}{lccc}
\hline Mortar & $\begin{array}{c}\text { Dry bulk } \\
\text { density }\left(\mathbf{k g} / \mathbf{m}^{3}\right)\end{array}$ & $\begin{array}{c}\text { SD } \\
\left(\mathbf{k g} / \mathbf{m}^{3}\right)\end{array}$ & $\begin{array}{c}\text { Homogeneous } \\
\text { groups }\end{array}$ \\
\hline MRA-100/0 & 1823.23 & 9.6 & $\mathrm{a}$ \\
MRA-75/25 & 1822.21 & 7.1 & $\mathrm{a}$ \\
MRA-50/50 & 1796.72 & 19.2 & $\mathrm{ab}$ \\
MRA-25/75 & 1788.54 & 11.0 & $\mathrm{bc}$ \\
MRA-0/100 & 1766.61 & 8.6 & $\mathrm{c}$ \\
\hline
\end{tabular}

\subsubsection{Compression strengths and flexural strengths}

The compressive and flexural strengths were measured at various cure times: 28, 91 and 150 days. The results can be seen in Table 8 and Figure 7. Figure 7 shows the evolution over time of the values of the compressive and flexural strengths for all types of mortar tested, similar results were also observed by Ledesma et al. (18) and Fernández-Ledesma et al. (38).

According to EN 998-2:2010, masonry mortars can be classified according to their compressive strength at 28 days, ranging from $1 \mathrm{MPa}$ to $20 \mathrm{MPa}$ (i.e., M1, M2.5, M5, M10, M15 and M20). Thus, the mortars studied belong to class M5. Comparing these results with the compressive strength classes proposed in EN 998-1:2010, all mortars with MRA belong to the classes CS III and CS IV, which are able for most applications. In terms of compressive strength, these results demonstrate that is it reasonably easy to manufacture masonry mortars containing RA, as per EN 998-2:2010.

Figure 8 compares the results of the compressive strength at 28 days cure with those obtained by Andrade et al. (13), Cuenca-Moyano et al. (15), Ledesma et al. (18) and Fernández-Ledesma et al. (38). The mechanical strength of the studied mortars increases linearly $\left(\mathrm{R}^{2}=0.86\right)$ as the MRA is incorporated, being, therefore, contrary to the results obtained by these authors. However, in general, these results are consistent with previous works $(22,39,40)$.

Although MRA produced mortars have higher water consumption and lower cement consumption, the increase in compressive strength observed (Figure 7 and 8) can be explained in three different ways: (i) the higher amount of very fine particles $(<0.075 \mathrm{~mm})$ of MRA and consequently its greater specific surface area $(10,15,34,40)$, provides a filler effect and makes mortars more compact and therefore more resistant; (ii) the higher coefficient of uniformity of the MRA gives greater compactness to the mixture, also contributing to increasing the mechanical strength; and (iii) the various pozzolanic reactions between the various phases that constitute this type of recycled material or the latent hydraulicity of the cementitious particles $(32,41)$ can also explain this behaviour. 
TABLE 8. Compressive strength of hardened mortar.

\begin{tabular}{|c|c|c|c|c|c|c|}
\hline Mortar & 28 days $(\mathrm{MPa})$ & SD (MPa) & 91 days $(\mathrm{MPa})$ & SD (MPa) & 150 days $(\mathrm{MPa})$ & SD (MPa) \\
\hline \multicolumn{7}{|c|}{ Compressive strength } \\
\hline MRA-100/0 & 6.66 & 0.27 & 9.53 & 0.70 & 10.77 & 1.19 \\
\hline MRA-75/25 & 7.54 & 0.09 & 10.55 & 0.12 & 11.17 & 0.40 \\
\hline MRA-50/50 & 7.60 & 0.32 & 10.99 & 1.63 & 12.70 & 1.19 \\
\hline MRA-25/75 & 7.71 & 0.21 & 11.24 & 1.62 & 12.99 & 1.51 \\
\hline MRA-0/100 & 8.58 & 0.25 & 11.46 & 0.18 & 15.07 & 1.90 \\
\hline \multicolumn{7}{|c|}{ Flexural strength } \\
\hline MRA-100/0 & 2.33 & 0.11 & 4.44 & 1.70 & 6.13 & 0.29 \\
\hline MRA-75/25 & 2.40 & 0.06 & 6.67 & 0.56 & 7.18 & 0.91 \\
\hline MRA-50/50 & 2.47 & 0.28 & 6.90 & 0.56 & 7.32 & 0.19 \\
\hline MRA-25/75 & 2.51 & 0.07 & 7.24 & 0.28 & 7.68 & 0.10 \\
\hline MRA-0/100 & 2.73 & 0.15 & 7.35 & 0.38 & 7.74 & 0.57 \\
\hline
\end{tabular}

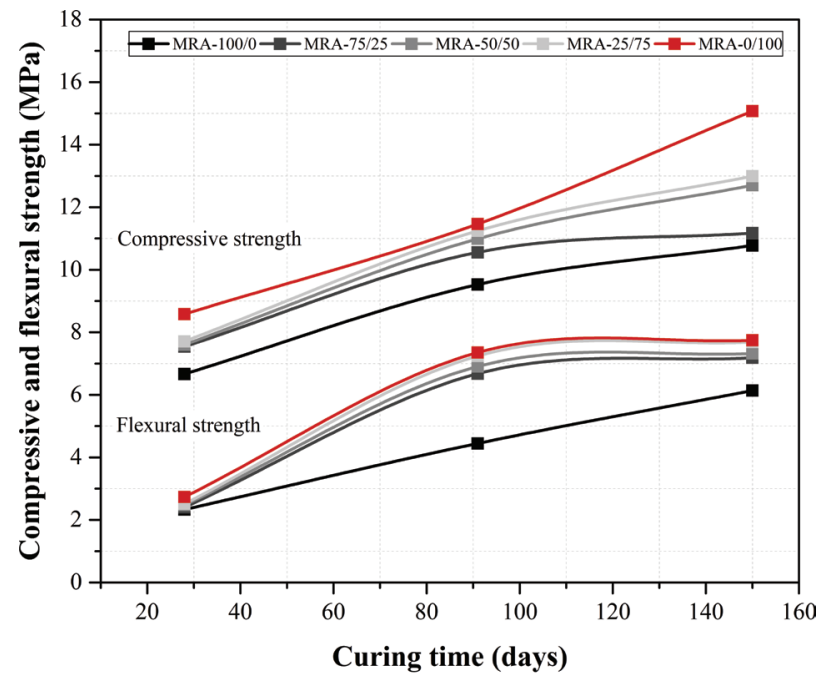

Figure 7. Compressive and flexural strength of hardened mortar over time.

In the case of the flexural strength, the same behaviour of the compressive strength was observed, that is, with the increase of the substitution, the flexural strength increases. These results are consistent with those obtained by Andrade et al. (13) up to 75\% substitution levels; and contrary to those obtained in other studies $(15,18,38)$, as can be observed Figure 9. The greatest flexural strength obtained in this research are due to the better physical adhesion between the matrix and the MRA, as well to its angular shape. This behaviour is important since the flexural strength may be related to the susceptibility to cracking and adhesive strength of rendering mortars (34).

Other effects may overlap and justify the increase in mechanical strength of mortars produced with MRA as such as (i) MRA absorbs free water during mixing, resulting in a reduction of the $\mathrm{w} / \mathrm{c}$ ratio of the transition zone (15); (ii) excess water becomes

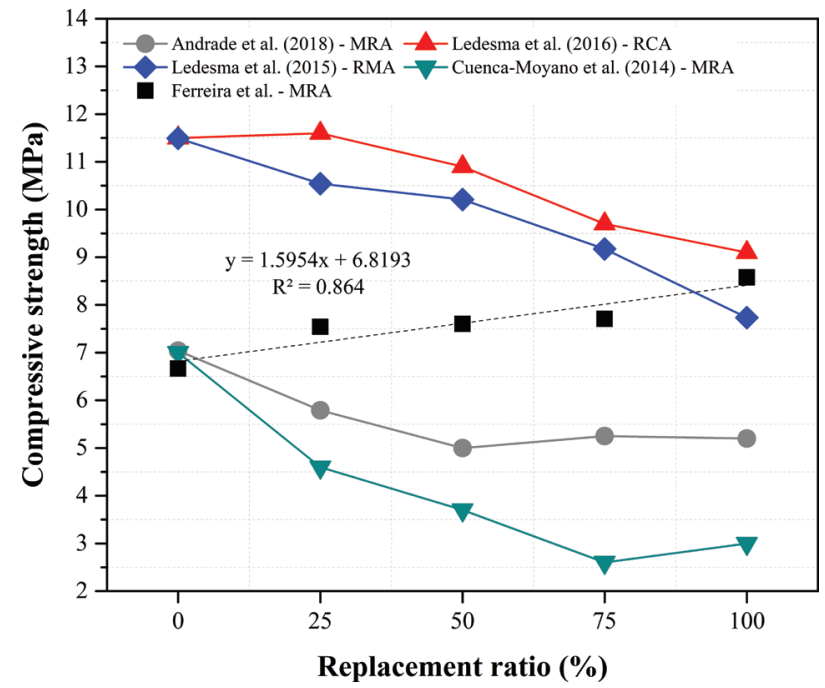

Figure 8. Compressive strength of hardened mortar at 28 days vs. replacement ratio.

available for better cement hydration (10); e (iii) the larger specific area of the MRA, as well as its elongated/flattened shape, improve the transition zone between the matrix and MRA $(10,14,15,34,40)$.

From the analysis of the XRD diagrams performed on the hardened mortars (Figure 10), the presence of gismondine in mortars with $100 \%$ MRA was identified due the higher percentage of $\mathrm{Al}_{2} \mathrm{O}_{3}$ oxide and the aluminate phases (muscovite, kaolinite, microcline and albite) present of the MRA. These greater amount of aluminates becomes available in the system to transform calcium hydroxide into gismondine (42). Gismondine (crystalline phase of Calcium Aluminosilicate Hydrate, CASH) is a type of thermodynamically stable hydration product from the pozzolan reaction and it can be precipitated at room temperature from the reaction of $\mathrm{C}_{2} \mathrm{~S}$ or calcium hydrous silicate $(\mathrm{CSH})$ with $\mathrm{AH}_{3}$ 


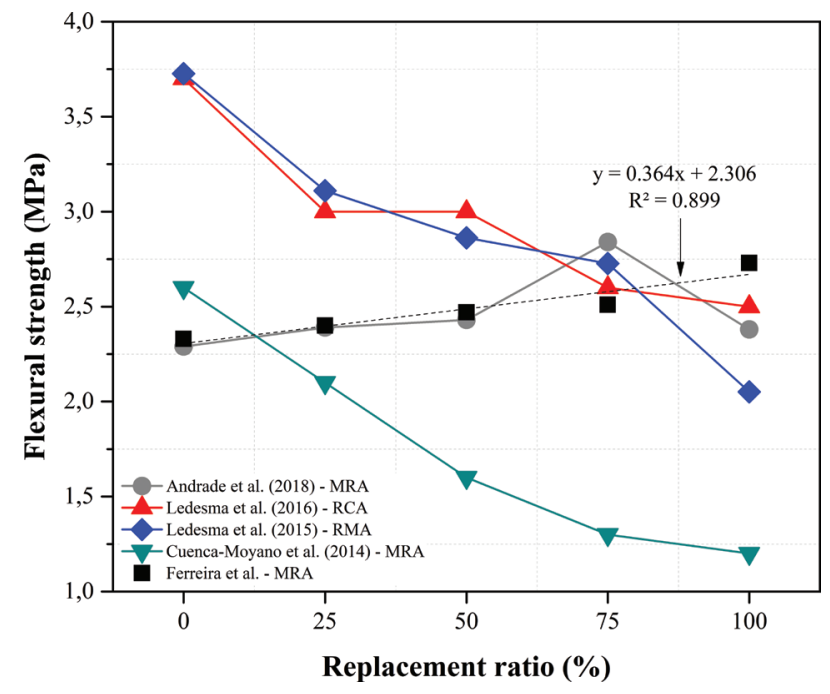

Figure 9. Flexural strength of hardened mortar at 28 days vs. replacement ratio.

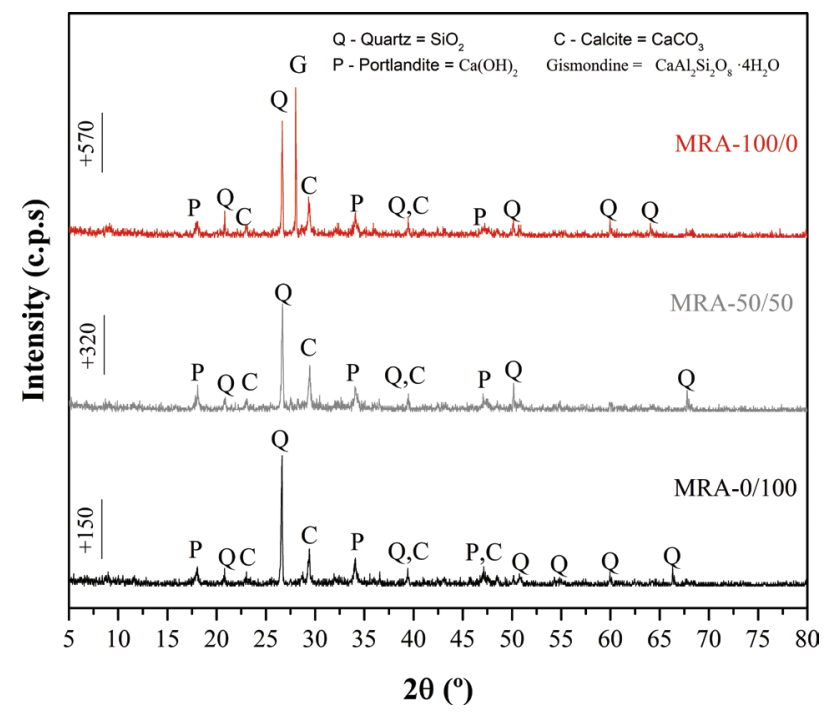

Figure 10. XRD of the mortars at 28 days of cure.

released or other calcium aluminate in the hydration process (43).

The increase of the chain of the compound of CASH also contributes to the densification of the matrix (44) and, consequently, to the mechanical strength of cementitious composites (45). This, therefore, also justifies the increase in the mechanical strength of the mortars with incorporation of $100 \%$ MRA.

These results confirmed that the addition of MRA does not have a negative effect on the mechanical strength of mortars. However, it is important to highlight that more resistant mortars are more prone to the appearance of cracking. The cracks may allow the entrance of water and other external agents in the masonry wall. This can contribute to
TABLE 9. Homogeneous groups for resistance to compression and bending of the mortars by curing time.

\begin{tabular}{lccc}
\hline & \multicolumn{3}{c}{ Homogeneous groups } \\
\cline { 2 - 4 } Mortar & $\mathbf{2 8}$ days & $\mathbf{9 1}$ days & $\mathbf{1 5 0}$ days \\
\hline Compressive strength & $\mathrm{c}$ & $\mathrm{a}$ & $\mathrm{b}$ \\
MRA-100/0 & $\mathrm{b}$ & $\mathrm{a}$ & $\mathrm{b}$ \\
MRA-75/25 & $\mathrm{b}$ & $\mathrm{a}$ & $\mathrm{ab}$ \\
MRA-50/50 & $\mathrm{b}$ & $\mathrm{a}$ & $\mathrm{ab}$ \\
MRA-25/75 & $\mathrm{a}$ & $\mathrm{a}$ & $\mathrm{a}$ \\
MRA-0/100 & 0.0000 & 0.1008 & 0.0009 \\
p-value & & & \\
Flexural strength & $\mathrm{a}$ & $\mathrm{b}$ & $\mathrm{a}$ \\
MRA-100/0 & $\mathrm{a}$ & $\mathrm{ab}$ & $\mathrm{a}$ \\
MRA-75/25 & $\mathrm{a}$ & $\mathrm{ab}$ & $\mathrm{a}$ \\
MRA-50/50 & $\mathrm{a}$ & $\mathrm{ab}$ & $\mathrm{a}$ \\
MRA-25/75 & $\mathrm{a}$ & $\mathrm{a}$ & $\mathrm{a}$ \\
MRA-0/100 & 0.1790 & 0.0398 & 0.0692 \\
p-value & & &
\end{tabular}

the occurrence of pathological manifestations, such as proliferation of fungi and mold and, in more extreme cases, causing detachments (34).

Table 9 shows that the p-value of the F-test indicated that there is a statistically significant difference between the mean values of compressive strength (at 28 and 150 days) and at flexural (at 91 days), from a replacement level for the other $\mathrm{p}$-value $<0.05$.

In relation to the multiple-range test, it was observed that- at 28 days- there is no statistically significant difference between the compressive strength of mortar with 25,50 and $75 \%$ of substitution. For flexural strength, all mortars are statistically the same regardless of the level of substitution. At 91 days: there is no statistically significant difference between the strengths to compression, regardless of the replacement level. On the other hand, for flexural strength, the test showed that between substitutions of 25 to $75 \%$ there are no statistically significant differences. At 150 days: there is no difference between the values of the compressive strength of the mortar with up to $75 \%$ of substitution. The flexural strength did not present statistically significant differences when increasing the substitution of NA by MRA.

\subsubsection{Water absorption and porosity}

The mortars produced with MRA absorb a greater amount of water and, therefore, are more porous (Figure 11). These results are in agreement with those obtained in previous studies $(13,14,24)$ and confirm that the high porosity of RA produces mortars with higher porosity in the hardened state.

The reason for the higher water absorption and porosity of mortars studied by Andrade et al. (13) 


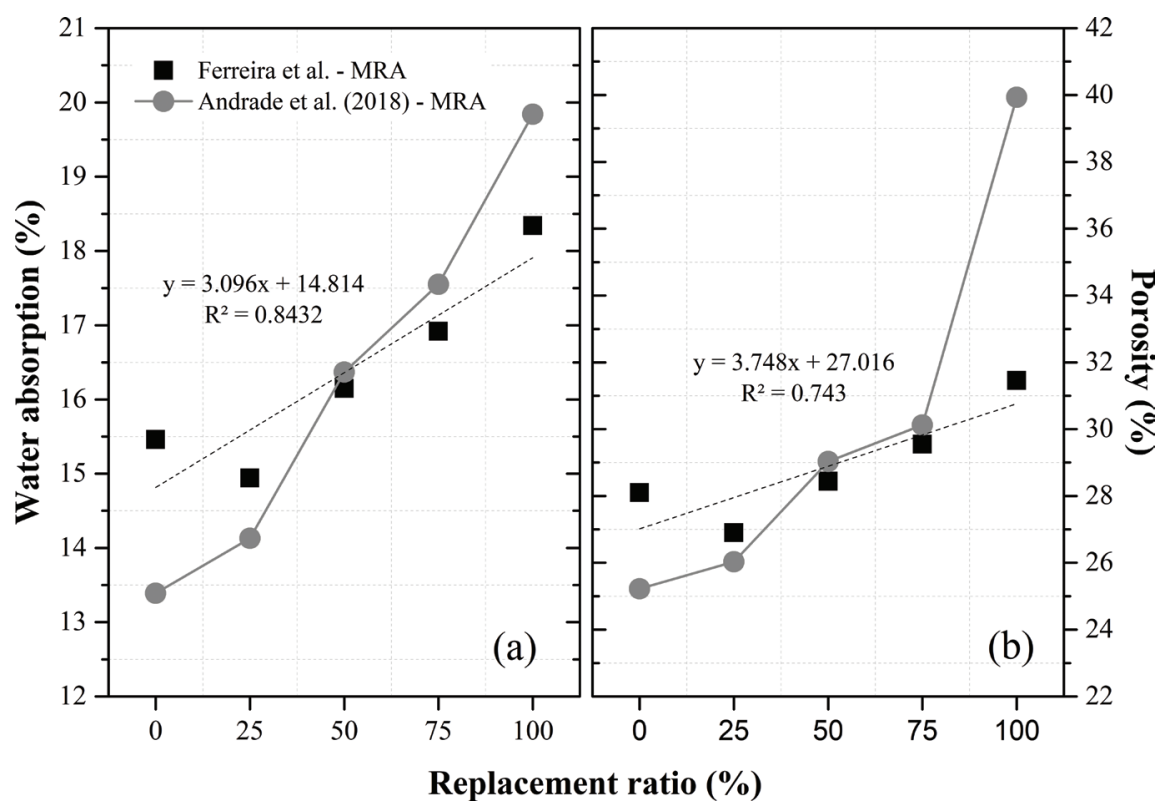

FIGURE 11. (a) Water absorption by immersion and (b) porosity of hardened mortar.

TABLE 10. Water absorption and porosity of hardened mortar.

\begin{tabular}{lcccccc}
\hline Mortar & $\begin{array}{c}\text { Water } \\
\text { absorption (\%) }\end{array}$ & SD (\%) & $\begin{array}{c}\text { Homogeneous } \\
\text { groups }\end{array}$ & Porosity (\%) & SD (\%) & $\begin{array}{c}\text { Homogeneous } \\
\text { groups }\end{array}$ \\
\hline MRA-100/0 & 15.46 & 0.05 & $\mathrm{~cd}$ & 28.13 & 0.11 & $\mathrm{c}$ \\
MRA-75/25 & 14.94 & 0.78 & $\mathrm{~d}$ & 26.90 & 1.19 & $\mathrm{bc}$ \\
MRA-50/50 & 16.15 & 0.64 & $\mathrm{bc}$ & 28.44 & 0.97 & $\mathrm{bc}$ \\
MRA-25/75 & 16.92 & 0.06 & $\mathrm{~b}$ & 29.55 & 0.14 & $\mathrm{~b}$ \\
MRA-0/100 & 18.34 & 0.17 & $\mathrm{a}$ & 31.46 & 0.30 & $\mathrm{a}$ \\
\hline
\end{tabular}

is possibly due to the lower hardened bulk density since usually, a lightweight mortar has higher pore volume. Others researches $(15,18,38)$ did not include this property in their studies.

Corinaldesi and Moriconi (14) mentioned that mortars produced with RA of CDW have higher open porosity due to the inherent porosity of these materials.

For all mortars and for the two analyzed properties (absorption and porosity), the p-value of the F-test was less than 0.05 (p-value $=0.0000$ ). Thus, the substitution percentage had a significant effect on the water absorption and porosity of the mortars. Table 10 shows the homogeneous groups identified in a multiple-range test. For water absorption, reference mortar (MRA-100/0) and with $25 \%$ of MRA (MRA-75/25) are statically equals; as well as mortars with 50 and $75 \%$ MRA (MRA-50/50 and MRA-25/75, respectively).

However, for the porosity the test indicated that mortars produced with MRA differ from the reference mortar (MRA-100/0) and those with substitution percentages of 25,50 and $75 \%$ do not differ among them.

\subsubsection{Capillary water absorption}

Figure 12 shows that MRA produced mortars absorbed less water by capillarity as NA is replaced by MRA, contrary to the results of other studies (18, 38 ) and the results of water absorption by immersion and porosity (Figure 11). The results obtained in this study resemble those obtained by CuencaMoyano et al. (15), although a linear decrease $\left(\mathrm{R}^{2}=\right.$ 0.89 ) in capillary absorption was not observed as the MRA was replaced.

Although it seems contradictory, since the MRA has high water absorption, this behaviour is justified by the greater compaction of the mortars, result of the physical effect of micro-filling of the voids by the fines of these aggregates. Similar results were obtained by other researchers $(19,22,32,34,40)$. It is also verified that other factors may have contributed to this performance as such as (i) limitation of water percolation due to the more angular and lamellar shape of the MRA; (ii) better hydration of the cement due to the release of the water absorbed during mixing in the internal structure of the 


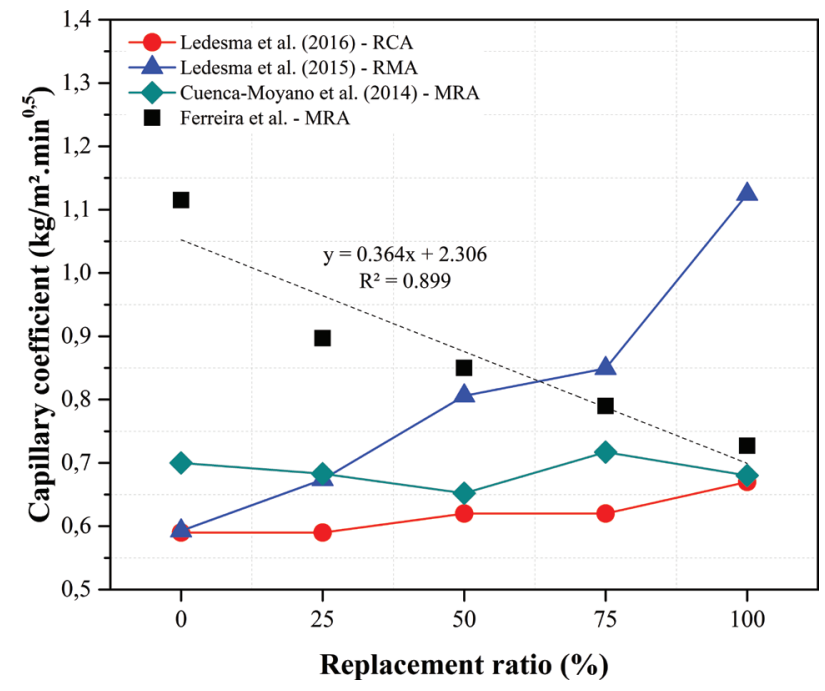

FIgURE. 12. Water absorption due to capillary of hardened mortar at 28 days vs. replacement ratio.

mortars (46) and (iii) the presence of cement with a high degree of hydration that possibly has lower porosity than the matrix itself (22). These observations are important, since capillary absorption is indirectly related to the durability of cementitious materials (34) and, therefore, a lower water absorption by capillarity suggests more durable rendering mortars when exposed to the action of external agents.

From a statistical standpoint, it was observed that the substitution percentage has a significant effect on capillary absorption, considering that the p-value of the F-test was less than 0.05 (p-value $=0.0001)$. The multiple range tests indicated that there are no statistically significant differences between mortars with $25 \%$ to $100 \%$ NA replacement by MRA (Table 11). Fernández-Ledesma et al. (38) did not find differences statistically significant differences for percentages of substitution inferior to $75 \%$. Jiménez et al. (32), in turn, found no major differences in this property with replacement rates of up to $40 \%$.

\section{CONCLUSIONS}

The use of mixed recycled aggregate (MRA) of construction and demolition waste (CDW) as a replacement for the natural aggregate (NA) for the production of masonry mortar was investigated in this work. Some important aspects of this investigation can be highlighted: (i) the use of MRA obtained from recycling plant; b) RA in natural condition, that is, as it is produced in the plant, without any previous treatment; c) use of the hydrated lime to improve the properties of mortars and decrease of cement consumption; d) use of procedures similar to those used in civil construction practice.
TABLE 11. Water absorption due to capillary of hardened mortar.

\begin{tabular}{|c|c|c|c|}
\hline Mortar & $\begin{array}{c}\text { Capillary } \\
\text { coefficient } \\
\left(\mathrm{kg} / \mathrm{m}^{2} \cdot \mathrm{min}^{0.5}\right)\end{array}$ & $\underset{\left(\mathrm{kg} / \mathrm{m}^{2} \cdot \min ^{0.5}\right)}{\mathrm{SD}}$ & $\begin{array}{l}\text { Homogeneous } \\
\text { groups }\end{array}$ \\
\hline MRA-100/0 & 1.12 & 0.07 & $\mathrm{a}$ \\
\hline MRA-75/25 & 0.80 & 0.05 & b \\
\hline MRA-50/50 & 0.87 & 0.04 & b \\
\hline MRA-25/75 & 0.79 & 0.06 & $\mathrm{~b}$ \\
\hline MRA-0/100 & 0.73 & 0.12 & b \\
\hline
\end{tabular}

The following conclusions can be drawn from this research:

- Mortar produced with MRA obtained adequate properties and even improved physical and mechanical properties compared to mortars made with NA. This improvement was due both to the adequate distribution of the grain size and to the greater content of fines present in the MRA.

- The higher content fines and friability particles of MRA contributed to the increase in fresh density and the reduction of the incorporated air content. On the other hand, the hardened bulk density decreases linearly as the MRA content increased due to the lower density of this aggregate.

- All the mortars studied showed an increase in their mechanical resistance over the cure time. The mean values of the compressive and flexural strengths increased linearly with the increase in MRA content, which confirms that the incorporation of MRA does not negatively affected on the mechanical strength of mortars.

- The incorporation of the MRA results in the production of mortars with greater capacity of water absorption and greater porosity. However, capillary absorption decreases as the amount of MRA increases.

From the results obtained, it can be observed that the use of the mixed fraction of CDW as a fine RA in cement-lime mortars is a viable alternative that improves most of the physical-mechanical properties of mortars. However, it is important to note that these conclusions are valid only for mixed recycled aggregates with adequate distribution of particle size and for a greater presence of fine particles $(<0.15 \mathrm{~mm})$. The replacement contributed to reducing the environmental impacts of waste generation and of the used abusive of natural resources. Therefore, it is expected that this research will contribute to the diffusion of the use of aggregates produced in CDW recycling plants by the construction industry, and, consequently, to reduce environmental impacts and achieve sustainable built environments. 


\section{ACKNOWLEDGEMENTS}

The authors are grateful to the IFRN Construction Materials Laboratory, to the Laboratory of Civil Construction and Structural Characterization of Materials of UFRN for the support during the accomplishment of this work and to the $\mathrm{CNPq}$ for the financial support through the project CNPqSETEC/ MEC N $N^{\circ}$ 17/2014 Linha 1: PD\&I.

\section{REFERENCES}

1. Kisku, N.; Joshi, H.; Ansari, M.; Panda, S.K.; Nayak, S.; Dutta, S.C. (2017) A critical review and assessment for usage of recycled aggregate as sustainable construction material. Constr. Build. Mater. 131, 721-740. https://doi. org/10.1016/j.conbuildmat.2016.11.029

2. Muñoz-Ruiperez, C.; Rodríguez, A.; Gutiérrez-González, S.; Calderón, V. (2016.) Lightweight masonry mortars made with expanded clay and recycled aggregates. Constr. Build. Mater. 118, 139-145. https://doi.org/10.1016/j. conbuildmat.2016.05.065

3. Silva, R. V.; De Brito, J.; Dhir, R.K. (2015) Prediction of the shrinkage behavior of recycled aggregate concrete: A review. Constr. Build. Mater. 77, 327-339. https://doi. org/10.1016/j.conbuildmat.2014.12.102

4. Pacheco-Torgal, F. (2017). High tech startup creation for energy efficient built environment. Renew. Sustain. Energy Rev. 71, 618-629. https://doi.org/10.1016/j.rser. 2016.12.088

5. Kulatunga, U.; Amaratunga, D.; Haigh, R.; Rameezdeen, R. (2006) Attitudes and perceptions of construction workforce on construction waste in Sri Lanka. Manag. Environ. Qual. An Int. J. 17, 57-72. https://doi. org/10.1108/14777830610639440

6. Krausmann, F.; Fischer-Kowalski, M.; Schandl, H.; Eisenmenger, N. (2008) The global sociometabolic transition: Past and present metabolic profiles and their future trajectories. J. Ind. Ecol. 12, 637-656. https://doi. org/10.1111/j.1530-9290.2008.00065.x

7. Tam, V.W.Y.; Soomro, M.; Evangelista, A.C.J. (2018) A review of recycled aggregate in concrete applications (2000-2017). Constr. Build. Mater. 172, 272-292. https:// doi.org/10.1016/j.conbuildmat.2018.03.240

8. Contreras, M.; Teixeira, S.R.; Lucas, M.C.; Lima, L.C.N.; Cardoso, D.S.L.; da Silva, G.A.C.; Gregório, G.C.; de Souza, A.E.; dos Santos, A. (2016) Recycling of construction and demolition waste for producing new construction material (Brazil case-study). Constr. Build. Mater. 123, 594-600. https://doi.org/10.1016/j.conbuildmat.2016.07.044

9. Paz, D.H.F.; Lafayette, K.P.V. (2016) Forecasting of construction and demolition waste in Brazil. Waste Manag. Res. 34 [8], 708-716. https://doi.org/10.1177/0734242X16644680

10. Cabral, A.E.B.; Schalch, V.; Molin, D.C.C.D. Ribeiro, J.L.D. (2010) Mechanical Properties Modeling of Recycled Aggregate Concrete. Constr. Build. Mater. 24 [4], 421-430. https://doi.org/10.1016/j.conbuildmat.2009.10.011

11. Moretti, J.P.; Sales, A.; Almeida, F.C.R.; Rezende, M.A.M.; Gromboni, P.P. (2016) Joint use of construction waste $(\mathrm{CW})$ and sugarcane bagasse ash sand (SBAS) in concrete. Constr. Build. Mater. 113, 317-323. https://doi. org/10.1016/j.conbuildmat.2016.03.062

12. Silva, R. V.; De Brito, J.; Dhir, R.K. (2014) Properties and composition of recycled aggregates from construction and demolition waste suitable for concrete production. Constr. Build. Mater. 65, 201-217. https://doi.org/10.1016/j. conbuildmat.2014.04.117

13. Andrade, J.J. de O.; Possan, E.; Squiavon, J.Z.; Ortolan, T.L.P. (2018) Evaluation of mechanical properties and carbonation of mortars produced with construction and demolition waste. Constr. Build. Mater. 161, 70-83. https:// doi.org/10.1016/j.conbuildmat.2017.11.089
14. Corinaldesi, V.; Moriconi, G. (2009) Behaviour of cementitious mortars containing different kinds of recycled aggregate. Constr. Build. Mater. 23 [1], 289-294. https://doi. org/10.1016/j.conbuildmat.2007.12.006

15. Cuenca-Moyano, G.M.; Martín-Morales, M.; ValverdePalacios, I.; Valverde-Espinosa, I.; Zamorano, M. (2014) Influence of pre-soaked recycled fine aggregate on the properties of masonry mortar. Constr. Build. Mater. 70, 71-79. https://doi.org/10.1016/j.conbuildmat.2014.07.098

16. Ferro, G.A.; Spoto, C.; Tulliani, J.M.; Restuccia, L. (2015) Mortar Made of Recycled Sand from C\&D. Procedia Eng. 109, 240-247. https://doi.org/10.1016/j.proeng.2015.06.224

17. Le, T.; Rémond, S.; Le Saout, G.; Garcia-Diaz, E. (2016) Fresh behavior of mortar based on recycled sand Influence of moisture condition. Constr. Build. Mater. 106, 35-42. https://doi.org/10.1016/j.conbuildmat.2015.12.071

18. Ledesma, E.F.; Jiménez, J.R.; Ayuso, J.; Fernández, J.M.; De Brito, J. (2015) Maximum feasible use of recycled sand from construction and demolition waste for eco-mortar production - Part-I: Ceramic masonry waste. J. Clean. Prod. 87, 692-706. https://doi.org/10.1016/j.jclepro.2014.10.084

19. Martínez, I.; Etxeberria, M.; Pavón, E.; Díaz, N. (2013) A comparative analysis of the properties of recycled and natural aggregate in masonry mortars. Constr. Build. Mater. 49, 384-392. https://doi.org/10.1016/j.conbuildmat. 2013.08.049

20. Restuccia, L.; Spoto, C.; Ferro, G.A.; Tulliani, J. (2016) Recycled Mortars with C\&D Waste. Procedia Struct. Integr. 2, 2896-2904. https://doi.org/10.1016/j.prostr.2016.06.362

21. Saiz Martínez, P.; Gonzảlez Cortina, M.; Fernández Martínez, F.; Rodríguez Sánchez, A. (2016) Comparative study of three types of fine recycled aggregates from construction and demolition waste (CDW), and their use in masonry mortar fabrication. J. Clean. Prod. 118, 162-169. https://doi.org/10.1016/j.jclepro.2016.01.059

22. Samiei, R.R.; Daniotti, B.; Dotelli, R.P.G. (2015). Properties of cement-lime mortars vs. cement mortars containing recycled concrete aggregates. Constr. Build. Mater. 84, 84-94. https://doi.org/10.1016/j.conbuildmat.2015.03.042

23. Zhao, Z; Remond, S.; Damidot, D.; Xu, W. (2015) Influence of fine recycled concrete aggregates on the properties of mortars. Constr. Build. Mater. 81, 179-186. https:// doi.org/10.1016/j.conbuildmat.2015.02.037

24. Moriconi, G.; Corinaldesi, V.; Antonucci, R. (2003) Environmentally-friendly mortars: a way to improve bond between mortar and brick. Mater. Struct. 36 [10], 702-708. https://link.springer.com/content/pdf/10.1007\% 2FBF02479505.pdf

25. Angulo, S.C.; Ulsen, C.; John, V.M., Kahn, H.; Cincotto, M.A. (2009) Chemical-mineralogical characterization of C\&D waste recycled aggregates from São Paulo, Brazil. Waste Manag. 29 [2], 721-730. https://doi.org/10.1016/j. wasman.2008.07.009

26. Ulsen, C.; Kahn, H.; Hawlitschek, G.; Masini, E.A.; Angulo, S.C.; John, V.M. (2013) Production of recycled sand from construction and demolition waste. Constr. Build. Mater. 40, 1168-1173. https://doi.org/10.1016/j. conbuildmat.2012.02.004

27. Bravo, M.; De Brito, J.; Pontes, J.; Evangelista, L. (2015) Durability performance of concrete with recycled aggregates from construction and demolition waste plants. Constr. Build. Mater. 77, 357-369. https://doi.org/10.1016/j. conbuildmat.2014.12.103

28. Bravo, M.; De Brito, J.; Pontes, J.; Evangelista, L. (2015) Mechanical performance of concrete made with aggregates from construction and demolition waste recycling plants. J. Clean. Prod. 99, 59-74. https://doi.org/10.1016/j. jclepro.2015.03.012

29. Cabral, A.E.B.; Schalch, V.; Molin, D.C.C.D.; Ribeiro, J.L.D. (2012) Performance estimation for concretes made with recycled aggregates of construction and demolition waste of some Brazilian cities. Mater. Res. 15 [6], 10371046. https://doi.org/10.1590/S1516-14392012005000119

30. Pereira, P.; Evangelista, L.; De Brito, J. (2012) The effect of superplasticizers on the mechanical performance of concrete made with fine recycled concrete aggregates. Cem. Concr. 
Compos. 34 [9], 1044-1052. https://doi.org/10.1016/j. cemconcomp.2012.06.009

31. Thomas, C.; Setién, J.; Polanco, J.A.; Alaejos, P.; Sánchez De Juan, M. (2013) Durability of recycled aggregate concrete. Constr. Build. Mater. 40, 1054-1065. https://doi. org/10.1016/j.conbuildmat.2012.11.106

32. Jiménez, J.R.; Ayuso, J.; López, M.; Fernández, J.M.; De Brito, J. (2013) Use of fine recycled aggregates from ceramic waste in masonry mortar manufacturing. Constr. Build. Mater. 40, 679-690. https://doi.org/10.1016/j. conbuildmat.2012.11.036

33. Lima, P.R.L.; Leite, M.B. (2012) Influence of CDW Recycled Aggregate on Drying Shrinkage of Mortar. Open J. Civ. Eng. 2 [2], 53-57. https://doi.org/10.4236/ojce.2012.22009

34. Silva, R. V.; De Brito, J.; Dhir, R.K. (2016) Performance of cementitious renderings and masonry mortars containing recycled aggregates from construction and demolition wastes. Constr. Build. Mater. 105, 400-415. https://doi. org/10.1016/j.conbuildmat.2015.12.171

35. Corinaldesi, V. (2012) Environmentally-friendly bedding mortars for repair of historical buildings. Constr. Build. Mater. 35, 778-784. https://doi.org/10.1016/j.conbuildmat.2012.04.131

36. Rodrigues, F.; Evangelista, L.; de Brito, J. (2013) A new method to determine the density and water absorption of fine recycled aggregates. Mater. Res. 16 [5], 1045-1051. https://doi.org/10.1590/S1516-14392013005000074

37. Gayarre, F.L.; Boadella, I.L.; Pérez, C.L.-C.; López, M.S.; Cabo, A.D. (2017) Influence of the ceramic recycled agreggates in the masonry mortars properties. Constr. Build. Mater. 132, 457-461. https://doi.org/10.1016/j. conbuildmat.2016.12.021

38. Fernández-Ledesma, E.; Jiménez, J.R.; Ayuso, J.; Corinaldesi, V.; Iglesias-Godino, F.J. (2016) A proposal for the maximum use of recycled concrete sand in masonry mortar design. Mater. Construcc. 66 [321], e075 http:// dx.doi.org/10.3989/mc.2016.08414.
39. Braga, M.; De Brito, J.; Veiga, R. (2015) Incorporation of fine sanitary ware aggregates in mortars. Constr. Build. Mater. 36, 960-968. https://doi.org/10.1016/j.conbuildmat. 2012.06.031

40. Neno, C.; De Brito, J.; Veiga, R. (2014) Using fine recycled concrete aggregate for mortar production. Mater. Res. 17 [1] 168-177. https://doi.org/10.1590/S1516-14392013005000164

41. Vegas, I.; Ibañez, J.A.; Lisbona, A.; Sáez De Cortazar, A.; Frías, M. (2011) Pre-normative research on the use of mixed recycled aggregates in unbound road sections. Constr. Build. Mater. 25 [5], 2674-2682. https://doi.org/10.1016/j. conbuildmat.2010.12.018

42. Antiohos, S.; Tsimas, S. (2004) Activation of fly ash cementitious systems in the presence of quicklime: Part I. Compressive strength and pozzolanic reaction rate. Cem. Concr. Res. 34 [5], 769-779. https://doi.org/10.1016/j. cemconres.2003.08.008

43. Vichan, S.; Rachan, R.; Horpibulsuk, S. (2013) Strength and microstructure development in Bangkok clay stabilized with calcium carbide residue and biomass ash. ScienceAsia 39, 186-193. https://doi.org/10.2306/ scienceasia1513-1874.2013.39.186

44. Tang, S.W.; Cai, X.H.; He, Z.; Shao, H.Y; Li, ZJ.; Chen, E. (2016) Hydration process of fly ash blended cement pastes by impedance measurement. Constr. Build. Mater. 113, 939-950. https://doi.org/10.1016/j.conbuildmat.2016.03.141

45. Zhang, Z.; Li, L.; Ma, X.; Wang, H. (2016) Compositional, microstructural and mechanical properties of ambient condition cured alkali-activated cement. Constr. Build. Mater. 113, 237-245. https://doi.org/10.1016/j. conbuildmat.2016.03.043

46. Yildirim, S.T.; Meyer, C.; Herfellner, S. (2015) Effects of internal curing on the strength, drying shrinkage and freeze - thaw resistance of concrete containing recycled concrete aggregates. Constr. Build. Mater. 91, 288-296. https://doi.org/10.1016/j.conbuildmat.2015.05.045 